\title{
Bioavailability of sediment-bound and algal metals to killifish Fundulus heteroclitus
}

\author{
Jessica Dutton*, Nicholas S. Fisher \\ School of Marine and Atmospheric Sciences, Stony Brook University, Stony Brook, New York 11794-5000, USA
}

\begin{abstract}
We used a radiotracer technique to experimentally assess whether $\mathrm{As}(\mathrm{V}), \mathrm{Cd}, \mathrm{Cr}(\mathrm{III})$, $\mathrm{Hg}(\mathrm{II})$, and methylmercury (MeHg) bound to sediment from 3 contaminated field sites (Baltimore Harbor, Elizabeth River, and Mare Island) and the green alga Dunaliella tertiolecta are bioavailable to killifish Fundulus heteroclitus. Algae are a component of the killifish diet in salt marshes, and although killifish do not actively consume sediment, some is accidentally ingested due to attachment to benthic prey. For both sediment and algae, the assimilation efficiencies (AE) of ingested metals were highest for $\mathrm{MeHg}$, followed by $\mathrm{Hg}(\mathrm{II}), \mathrm{As}$, and $\mathrm{Cd}$, and lowest for Cr. Following sediment intubations, AE values ranged from $0.01-0.03 \%(\mathrm{Cr})$ to $10-14 \%(\mathrm{MeHg})$, and ranged from $0.7 \%(\mathrm{Cr})$ to $82 \%(\mathrm{MeHg})$ following algal intubation. Following sediment intubations, loss rate constants $\left(k_{\mathrm{ef}}\right)$ were similar for $\mathrm{As}, \mathrm{Cd}$, and $\mathrm{Hg}(\mathrm{II})$ and lowest for $\mathrm{MeHg}$, whereas following algal intubation, the $k_{\text {ef }}$ values were highest for As, followed by $\mathrm{Cr}, \mathrm{Hg}(\mathrm{II})$, and Cd, and lowest for $\mathrm{MeHg}$. At the end of depuration, tissue distribution data showed that $\mathrm{Cd}$ and $\mathrm{Hg}$ (II) remained primarily associated with the viscera, whereas As and MeHg were distributed throughout the body. Calculated trophic transfer factors (TTF) showed that only MeHg bound to algae, and Elizabeth River sediment is expected to biomagnify at this trophic step (TTF $>1$ ). Metals can accumulate to high concentrations in sediment in industrialized coastal areas, but the present study indicates that the risk of exposure for killifish from ingesting contaminated sediment is minimal.
\end{abstract}

KEY WORDS: Fish $\cdot$ Metal bioaccumulation $\cdot$ Sediment $\cdot$ Algae $\cdot$ Trophic transfer factors

\section{INTRODUCTION}

Sediments are a major repository for trace metals, especially in coastal regions, where metal concentrations can reach elevated levels in industrialized estuaries (Kennish 1997). Sediments are much more enriched in metals than the overlying water column. This enrichment provides a large source of metals to benthic organisms, potentially impacting their health or that of their predators. Many factors influence whether a particular metal is bioavailable, and the mechanisms involved are still being studied. Field studies have shown that benthic organisms can accumulate metals to high concentrations, including in industrialized coastal waters and salt marshes where killifish reside (Kennish 1997, França et al. 2005).
The bioavailability of sediment-bound metal to benthic organisms is dependent on the sediment geochemistry and phase-partitioning of the metal (Luoma 1989, Wang et al. 1999, Baumann \& Fisher 2011) and the time of sediment exposure to the metal (Wang et al. 1999, Griscom et al. 2000, Baumann \& Fisher 2011). Studies using radiotracers have shown that polychaetes, bivalves, and amphipods can assimilate sediment-bound metals (Wang et al. 1999, Schlekat et al. 2000, Griscom et al. 2002a, Baumann \& Fisher 2011), and these organisms can act as a conduit for the trophic transfer of metals to higher trophic levels, including fish, birds, and potentially human consumers of seafood.

Within the planktonic food chain, the largest enrichment step occurs at the bottom of the food chain, 
between the dissolved phase and phytoplankton (Fisher \& Reinfelder 1995). Sinking planktonic debris enriched in metals can settle to sediments and serve as a source of metal for benthic animals in addition to the metals that sorb directly to the sediments themselves (Baumann \& Fisher 2011).

The killifish, or mummichog, Fundulus heteroclitus inhabits estuaries, bays, and salt marshes along the eastern seaboard of the United States from the Gulf of St. Lawrence to northeastern Florida (Abraham 1985). Killifish gut content analyses have shown that they consume a varied diet, including algae, amphipods, copepods, polychaetes, nematodes, molluscs, crabs, eggs, plant material, and detritus (Kneib \& Stiven 1978, Allen et al. 1994, McMahon et al. 2005). While gut content analyses have not shown that killifish actively consume sediment, some sediment may be accidently ingested while feeding on benthic prey, and the metals associated with this sediment may be bioavailable to killifish.

To investigate the bioavailability of sedimentbound and algal metals to killifish, we radiolabeled sediment from 3 contaminated field sites (Baltimore Harbor, Elizabeth River, and Mare Island) and the green alga Dunaliella tertiolecta with $\mathrm{As}, \mathrm{Cd}, \mathrm{Cr}$, $\mathrm{Hg}(\mathrm{II})$, and methylmercury (MeHg). The transfer of these metals to killifish was assessed after the fish were intubated with sediment or algae. Following intubation, metal loss was monitored for $9 \mathrm{~d}$, and kinetic parameters (assimilation efficiencies, or percentage of ingested material that crosses the gut lining, and loss rate constants) and tissue distributions of the ingested metal were determined. The kinetic parameters were used to calculate the trophic transfer factor (TTF), which describes the likelihood that a metal will be transferred from food to fish at this trophic step. The 3 sediment locations were chosen because they are all contaminated, have differing organic carbon content, grain size distribution, and geochemical properties (Baumann \& Fisher 2011), and are part of a larger project comparing these sites. $D$. tertiolecta was the chosen alga because it has no cell wall, therefore minimizing the digestive complication of a walled cell.

The 3 metals $(\mathrm{Cd}, \mathrm{Cr}$, and $\mathrm{Hg})$ and metalloid (As) were chosen based upon their chemical characteristics and environmental interest. Among the chosen trace elements, $\mathrm{Hg}$ is a Class B metal with a greater affinity for sulfur ligands than oxygen or nitrogen ligands, whereas As, Cd, and $\mathrm{Cr}$ are borderline metals (Nieboer \& Richardson 1980). These metals are commonly found at elevated concentrations in estuarine sediments, particularly those near industrial areas (Kennish 1997), and their bioavailability is of interest for management of coastal ecosystems.

\section{MATERIALS AND METHODS}

\section{Study locations and sediment collection}

Sediment was collected by box coring from 2 contaminated sites in the Chesapeake Bay, the Elizabeth River (ER; Norfolk, VA; $36^{\circ} 12^{\prime} 32^{\prime \prime} \mathrm{N}, 76^{\circ} 20^{\prime} 09^{\prime \prime} \mathrm{W}$ ) in May 2006 and Baltimore Harbor $\left(\mathrm{BH}_{;}\right.$Baltimore, $\mathrm{MD}$; $39^{\circ} 12^{\prime} 25^{\prime \prime} \mathrm{N}, 76^{\circ} 31^{\prime} 41^{\prime \prime} \mathrm{W}$ ) in June 2007, and one contaminated site in San Francisco Bay, the Mare Island naval complex (MI; Vallejo, $\mathrm{CA}_{i} 38^{\circ} 04^{\prime} 23^{\prime \prime} \mathrm{N}$, $122^{\circ} 14^{\prime} 91^{\prime} \mathrm{W}$ ) in October 2007 . The grain size distribution (described as the percentage of the coarse fraction $>63 \mu \mathrm{m}$ ), organic carbon content, and background metal concentrations for each location are shown in Table 1. For grain size analysis, $\sim 20 \mathrm{~g}$ of sediment was dried at $60^{\circ} \mathrm{C}$ to obtain a total dry weight, rehydrated, and separated into coarse $(>63 \mu \mathrm{m})$ and fine $(<63 \mu \mathrm{m})$ fractions by wet sieving. The coarse fraction was then dried at $60^{\circ} \mathrm{C}$ for $48 \mathrm{~h}$ to obtain dry weights ( $\mathrm{n}=3$ per field site). Organic carbon content was calculated by combusting dry sediment at $450^{\circ} \mathrm{C}$ for $6 h_{i}$ the percentage difference between the before and after dry weights was the percentage of organic carbon. Background metal concentrations were analyzed by inductively coupled plasma-mass spectrometry (ICP-MS) at the Trace Element Core Laboratory (Dartmouth College, Hanover, $\mathrm{NH}$, USA) using an IAEA-433 reference standard.

Water from each field location was collected using a trace metal clean pump, and the chemical properties (salinity, dissolved organic carbon [DOC] concentration, and background metal concentrations)

Table 1. Sediment properties. Percentage of sediment $>63 \mu \mathrm{m}$ in size (coarse fraction), organic carbon content, and background concentration of metals (As, Cd, $\mathrm{Cr}$, total $\mathrm{Hg}$ ) for sediment collected from Baltimore Harbor $(\mathrm{BH})$, Elizabeth River (ER), and Mare Island (MI). Values are means $\pm 1 \mathrm{SD} ; \mathrm{n}=3$

\begin{tabular}{|ccccccc|}
\hline & $\begin{array}{c}\text { Coarse } \\
\text { fraction (\%) }\end{array}$ & Organic carbon & \multicolumn{4}{c}{ Background conc. $\left(\mathrm{mg} \mathrm{kg}^{-1}\right)$} \\
& Content (\%) & As & Cd & Cr & Hg \\
\hline BH & $8.4 \pm 1.3$ & $5.5 \pm 0.3$ & $26 \pm 0.3$ & $0.5 \pm 0.02$ & $116 \pm 10$ & $0.2 \pm 0.1$ \\
ER & $12 \pm 0.7$ & $7.5 \pm 0.6$ & $13 \pm 0.5$ & $0.9 \pm 0.03$ & $38 \pm 2.4$ & $0.2 \pm 0.2$ \\
MI & $9.4 \pm 0.5$ & $4.2 \pm 0.1$ & $8.8 \pm 0.4$ & $0.4 \pm 0.05$ & $72 \pm 1.7$ & $0.1 \pm 0.07$ \\
\hline
\end{tabular}


Table 2. Water properties. Salinity, dissolved organic carbon (DOC) concentration, and background metal concentrations (As, Cd, Cr, and total $\mathrm{Hg}$ ) for water collected from Baltimore Harbor (BH), Elizabeth River (ER), and Mare Island (MI). For DOC concentration, values are means $\pm 1 \mathrm{SD}_{i} \mathrm{n}=3$. For background metal concentrations, units are $\mu \mathrm{g} \mathrm{l}^{-1}$ for $\mathrm{As}, \mathrm{Cd}$, and $\mathrm{Cr}$ and $\mathrm{ng}^{-1}$ for $\mathrm{Hg}$

\begin{tabular}{|ccccccc|}
\hline & \multirow{2}{*}{ Salinity } & \multirow{2}{*}{ DOC conc. } & \multicolumn{4}{c|}{ Background conc. } \\
& & $(\mu \mathrm{M})$ & As & Cd & Cr & Hg \\
\hline BH & 7.6 & $219 \pm 12$ & 0.97 & 0.02 & 0.19 & 2.9 \\
ER & 19.5 & $384 \pm 1.9$ & 1.38 & 0.21 & 0.25 & 3.4 \\
MI & 22 & $169 \pm 6.7$ & 2.20 & 0.19 & 0.20 & 2.7 \\
& & & & & & \\
\hline
\end{tabular}

are shown in Table 2. The Hg background water concentration was also analyzed at Dartmouth College, and $\mathrm{As}, \mathrm{Cd}$, and $\mathrm{Cr}$ were analyzed at Rutgers Inorganic Analytical Core Laboratory (Rutgers University, New Brunswick, NJ, USA) using ICP-MS. All of the water was $0.2 \mu \mathrm{m}$ sterile-filtered (Millipak 200, Millipore) before use. The sediment and water were held in the dark at $4^{\circ} \mathrm{C}$ until use.

\section{Fish maintenance}

Field-collected (Taylor River, Hampton, NH, USA) killifish Fundulus heteroclitus, $59.5 \pm 2.2 \mathrm{~mm}$ (mean \pm $\mathrm{SD}$ ) long and with a mean wet weight of $2.1 \pm 0.3 \mathrm{~g}$, were purchased from Aquatic Research Organisms and acclimated to experimental conditions for at least $4 \mathrm{wk}$ prior to the start of the experiments. The fish were fed a diet of TetraCichlid ${ }^{\mathrm{TM}}$ cichlid flakes (Tetra Holding) and frozen bloodworms daily prior to the start of the experiments and were fed only bloodworms throughout the experiments. All fish were starved for $36 \mathrm{~h}$ prior to the start of the experiments to allow for total gut clearance. Fish were held at $18 \pm$ $0.5^{\circ} \mathrm{C}$ on a $14: 10 \mathrm{~h}$ light:dark cycle.

\section{Metal uptake from sediment}

To prepare radiolabeled sediment, $\sim 6$ to $6.5 \mathrm{~g}$ of sediment from each of the 3 field locations were radiolabeled and left to age in the dark in sealed glass containers at room temperature $\left(20 \pm 1^{\circ} \mathrm{C}\right)$ for $7 \mathrm{~d}$. Comparisons of wet and dry weights indicated that water comprised $\sim 56 \%$ of the weight of sediment from $\mathrm{BH}, 63 \%$ from $\mathrm{ER}$, and $52 \%$ from MI. Radioisotope additions per field location were 104 kilobecquerel $(\mathrm{kBq}){ }^{73} \mathrm{As}, 40 \mathrm{kBq}{ }^{109} \mathrm{Cd}, 245 \mathrm{kBq}{ }^{51} \mathrm{Cr}, 33 \mathrm{kBq}$ ${ }^{203} \mathrm{Hg}(\mathrm{II})$, and $33 \mathrm{kBq} \mathrm{MeHg}$; this corresponds to the following metal concentrations: $511 \mathrm{nM}{ }^{73} \mathrm{As}$, $103 \mathrm{nM}{ }^{109} \mathrm{Cd}, 54 \mathrm{nM}{ }^{51} \mathrm{Cr}, 195 \mathrm{nM}{ }^{203} \mathrm{Hg}(\mathrm{II})$, and $195 \mathrm{nM} \mathrm{MeHg}$. At the end of the $7 \mathrm{~d}$ sediment aging period, killifish were intubated with radiolabeled sediment ( $\mathrm{n}=5$ per field site). To intubate killifish, radiolabeled sediment was added to a $3 \mathrm{~cm}^{3}$ syringe with a 16G1 1/2 PrecisionGlide needle attached (Becton Dickinson), and the needle was carefully slid into intramedic non-radiopaque polyethylene tubing (internal diameter $1.57 \mathrm{~mm}, 5 \mathrm{~cm}$ long; Clay Adams). Fish were removed from the water, and the tubing was passed through the mouth and esophagus into the start of the intestine, where $\sim 0.06$ to $0.1 \mathrm{~g}$ of radiolabeled sediment was added. The fish were then returned to the water and not handled for $30 \mathrm{~min}$ to minimize stress and prevent sediment regurgitation. No feces were produced during this time, so the start of depuration was when the fish were intubated. No fish died or showed adverse effects (not feeding or abnormal swimming behavior) due to this intubation procedure.

After determining their initial radioactivity, the fish were returned to individual containers with non-radiolabeled water, collected from the same field location as the sediment, and fed non-radiolabeled bloodworms to purge their guts of radiolabeled sediment. Fish were radioassayed at regular intervals during the first $2 \mathrm{~d}$ and then once a day for the following $7 \mathrm{~d}$ to evaluate metal loss. At each sample time, feces and a $1 \mathrm{ml}$ water sample were collected. The depuration water was changed after $1 \mathrm{~d}$ and then every other day to minimize any radioisotope leaching into the dissolved phase, either due to release from feces or excretion from the fish. At the end of the $9 \mathrm{~d}$ depuration period, the fish were euthanized using MS222 and dissected into head (including gills), viscera, and body (skeleton, fins, fillet, and skin). The radioactivity of each tissue compartment was determined, after which the samples were dried at $60^{\circ} \mathrm{C}$ for $48 \mathrm{~h}$ to determine dry weights.

Statistical analyses were conducted using IBM SPSS statistics software (v. 20). One-way ANOVA and Tukey post-hoc tests were conducted to identify significant differences $(p<0.05$ or $p<0.01)$ between sediment location and kinetic parameters (assimilation efficiencies and loss rate constants) for each metal.

\section{Metal uptake from algae}

The green alga Dunaliella tertiolecta (CCMP 1320) was uniformly radiolabeled with metals for $4 \mathrm{~d}$ in 
11 (2 flasks containing $500 \mathrm{ml}$ each) of $\mathrm{BH}$ water, amended with nutrients at $\mathrm{f} / 2$ concentrations (Guillard \& Ryther 1962) but modified so no $\mathrm{Cu}, \mathrm{Zn}$, or EDTA were added. Phosphate was added at an $\mathrm{f} / 200$ concentration for the ${ }^{73} \mathrm{As}$ treatment, due to competition for uptake between As and $\mathrm{PO}_{4}$ (Sanders \& Windom 1980). Radioisotope additions per $500 \mathrm{ml}$ were $69 \mathrm{kBq}{ }^{73} \mathrm{As}, 20 \mathrm{kBq}{ }^{109} \mathrm{Cd}, 66 \mathrm{kBq}{ }^{51} \mathrm{Cr}, 4.2 \mathrm{kBq}$ ${ }^{203} \mathrm{Hg}(\mathrm{II})$, and $4.2 \mathrm{kBq} \mathrm{MeHg}$, corresponding to the following metal concentrations: $3.68 \mathrm{nM}{ }^{73} \mathrm{As}$, $0.69 \mathrm{nM}{ }^{109} \mathrm{Cd}, 1.04 \mathrm{nM}{ }^{51} \mathrm{Cr}, 2.01 \mathrm{nM}{ }^{203} \mathrm{Hg}$ (II), and $2.01 \mathrm{nM} \mathrm{MeHg}$. At the start of uptake, D. tertiolecta cell density $\left(\mathrm{ml}^{-1}\right)$ was $5.7 \times 10^{5}$ for ${ }^{73} \mathrm{As}$ and ${ }^{51} \mathrm{Cr}$, 6.4 $\times 10^{5}$ for ${ }^{109} \mathrm{Cd}, 3.9 \times 10^{5}$ for ${ }^{203} \mathrm{Hg}(\mathrm{II})$, and $7.6 \times 10^{5}$ for MeHg. Following uptake, the percentage of radioisotope associated with cells ( $\mathrm{n}=2$ ) was $70 \%$ for ${ }^{73} \mathrm{As}$, $55 \%$ for ${ }^{109} \mathrm{Cd}$, $83 \%$ for ${ }^{51} \mathrm{Cr}$, $79 \%$ for ${ }^{203} \mathrm{Hg}$ (II), and $55 \%$ for $\mathrm{MeHg}$, and the cell density $\left(\mathrm{ml}^{-1}\right)$ increased to $3.1 \times 10^{6}$ for ${ }^{73} \mathrm{As}$ and ${ }^{51} \mathrm{Cr}, 5.7 \times 10^{6}$ for ${ }^{109} \mathrm{Cd}, 1 \times$ $10^{6}$ for ${ }^{203} \mathrm{Hg}(\mathrm{II})$, and $6.9 \times 10^{6}$ for MeHg. Cell counts were obtained using a Beckman Coulter ${ }^{\mathrm{TM}}$ Multisizer $^{\mathrm{TM}} 3$ Coulter Counter. The algal suspensions were filtered through $0.2 \mu \mathrm{m}$ polycarbonate membranes and rinsed 4 times with non-radiolabeled Baltimore Harbor water to remove excess radioisotope associated with the cell surface. The algal cells were then gently scraped off the filter using a scalpel and resuspended in $3 \mathrm{ml}$ of non-radiolabeled Baltimore Harbor water to make an algal slurry. The intubation procedure followed that described for the sediment intubation (except a $1 \mathrm{~cm}^{3}$ tuberculin syringe [Becton Dickinson] was used), and the fish were intubated with $\sim 0.25 \mathrm{ml}$ of the algal slurry ( $\mathrm{n}=10$ for $\mathrm{As}, \mathrm{Cd}, \mathrm{Cr}$, and $\mathrm{Hg}(\mathrm{II}) ; \mathrm{n}=9$ for $\mathrm{MeHg}$ ). The depuration and dissection procedure followed what was previously described.

\section{Radioisotopes and radioanalyses}

High specific activity gamma-emitting radioisotopes were used in the present study (10.97 to $13.97 \mu \mathrm{Ci}$ $\mu \mathrm{g}^{-1}{ }^{73} \mathrm{As}$, 13.88 to $14.43 \mu \mathrm{Ci} \mu \mathrm{g}^{-1}{ }^{109} \mathrm{Cd}^{-6} 67.58$ to $340.8 \mu \mathrm{Ci} \mu \mathrm{g}^{-1}{ }^{51} \mathrm{Cr}, 0.55$ to $3.22 \mu \mathrm{Ci} \mu \mathrm{g}^{-1}{ }^{203} \mathrm{Hg}$ (II), and 0.55 to $3.22 \mu \mathrm{Ci} \mathrm{ug}^{-1} \mathrm{MeHg}$ ). The ${ }^{73} \mathrm{As}$ (half-life $\left[\mathrm{t}_{1 / 2}\right]=80.3 \mathrm{~d}$, as As(V)) and ${ }^{109} \mathrm{Cd}\left(\mathrm{t}_{1 / 2}=462.6 \mathrm{~d}\right)$, both dissolved in $0.1 \mathrm{M} \mathrm{HCl}$, were purchased from the Department of Energy (Los Alamos National Laboratory), ${ }^{51} \mathrm{Cr}\left(\mathrm{t}_{1 / 2}=27.7 \mathrm{~d}\right.$, as $\mathrm{Cr}(\mathrm{III})$, dissolved in $0.5 \mathrm{M}$ $\mathrm{HCl})$ was purchased from PerkinElmer, and ${ }^{203} \mathrm{Hg}$ (II) $\left(\mathrm{t}_{1 / 2}=46.6 \mathrm{~d}\right.$, as $\mathrm{Hg}(\mathrm{II})$, dissolved in $\left.1 \mathrm{M} \mathrm{HCl}\right)$ was purchased from Eckert \& Ziegler Isotope Products. $\mathrm{MeHg}\left(\mathrm{CH}_{3}{ }^{203} \mathrm{Hg}(\mathrm{II})\right)$ was synthesized in our labora- tory using a method described by Rouleau \& Block (1997) and held in deionized water. The radioisotopes were added in microliter quantities, and equimolar concentrations of sodium hydroxide were added to neutralize the acid. The $\mathrm{pH}$ remained unchanged after radioisotope additions. ${ }^{109} \mathrm{Cd},{ }^{203} \mathrm{Hg}(\mathrm{II})$, and $\mathrm{MeHg}$ were single-labeled, while ${ }^{73} \mathrm{As}$ and ${ }^{51} \mathrm{Cr}$ were double labeled.

Live fish were radioassayed using a Canberra deep-well $\mathrm{NaI}(\mathrm{Tl}) \boldsymbol{\gamma}$-detector for no longer than $5 \mathrm{~min}$ to minimize stress on the fish. Initially, the propagated counting error was $\leq 5 \%$, but after gut clearance, propagated counting errors could reach $25 \%$ due to much lower radioactivity caused by elimination of the radioisotope. Water, feces, and dissected fish tissue were radioassayed using an intercalibrated LKB Pharmacia-Wallac 1282 CompuGamma CS gamma-counter for $5 \mathrm{~min}\left({ }^{73} \mathrm{As},{ }^{109} \mathrm{Cd}\right.$, and $\left.{ }^{51} \mathrm{Cr}\right)$ or $10 \mathrm{~min}\left({ }^{203} \mathrm{Hg}\right)$. The $\gamma$-emission of ${ }^{109} \mathrm{Cd},{ }^{73} \mathrm{As}$, ${ }^{203} \mathrm{Hg}$, and ${ }^{51} \mathrm{Cr}$ was detected at 22, 53, 279, and $320 \mathrm{keV}$, respectively. All sample counts were adjusted for background radioactivity and radioactive decay.

\section{Modeling metal bioaccumulation in killifish}

The steady-state concentration of metals in aquatic organisms can be determined using a well-described biokinetic model (Thomann 1981, Wang et al. 1996, Reinfelder et al. 1998). This model takes into account the uptake and loss of metals following aqueous and dietary exposure. We did not determine metal uptake from the aqueous phase in our study, but the dietary component of the model can be rearranged to calculate the TTF. The TTF estimates the likelihood for a metal to biomagnify at a particular trophic step, based on the ratio of metal in a predator compared to metal in its prey. A TTF $>1$ indicates that biomagnification is likely at this trophic step, whereas a TTF $<1$ indicates there is a low probability of biomagnification (Reinfelder et al. 1998). TTF is calculated as follows:

$$
\mathrm{TTF}=(\mathrm{AE} \cdot \mathrm{IR}) / k_{\mathrm{ef}}
$$

where $\mathrm{AE}$ is the assimilation efficiency of the ingested metal (fraction), IR is the weight-specific ingestion rate $\left(\mathrm{g} \mathrm{g}^{-1} \mathrm{~d}^{-1}\right)$, and $k_{\text {ef }}$ is the metal loss rate constant after dietary exposure $\left(\mathrm{d}^{-1}\right)$. Metals with a high $\mathrm{AE}$ and low $k_{\text {ef }}$ have a greater probability of biomagnifying, compared to those with a low AE and high $k_{\text {ef. }}$.

The AE and $k_{\text {ef }}$ for individual fish following sediment and algal intubations were calculated by exponentially regressing metal retention between $48 \mathrm{~h}$ 
and $216 \mathrm{~h}$ of depuration. The $\mathrm{AE}$ was determined to be the $y$-intercept, and the $k_{\text {ef }}$ was the slope of the curve. The $\mathrm{Cr} \mathrm{AE}$ after sediment intubation was calculated as the percentage remaining after $48 \mathrm{~h}$ of depuration, due to nearly complete elimination of the radioisotope. An average IR value was obtained from the literature $\left(0.07 \mathrm{~g} \mathrm{~g}^{-1} \mathrm{~d}^{-1}\right)$ (Prinslow et al. 1974).

The biological half-life $\left(\mathrm{tb}_{1 / 2 i}\right.$ defined as the time it takes for $50 \%$ of a metal to be excreted from the body) of a metal can be calculated to estimate a metal's residence time in an organism as follows:

$$
\mathrm{tb}_{1 / 2}=\ln 2 / k_{\mathrm{ef}}
$$

\section{RESULTS}

\section{Assimilation and retention of metals after sediment intubation}

After intubation with radiolabeled sediment, the $\mathrm{AE}$ values were highest for $\mathrm{MeHg}$ (10 to $14 \%$ ), followed by $\mathrm{Hg}$ (II) (1.9 to $4.1 \%$ ), As (0.8 to $1.7 \%$ ), and $\mathrm{Cd}$ $(0.04$ to $0.3 \%)$, and lowest for $\mathrm{Cr}(0.01$ to $0.03 \%$ ) (Table 3 ). The AE values for each field location did not differ significantly from each other for $\mathrm{Cr}$, $\mathrm{Hg}(\mathrm{II})$, and $\mathrm{MeHg}(\mathrm{p}>0.05)$, but the values did differ for As $(p<0.05$; ER vs. $\mathrm{MI})$ and $\mathrm{Cd}(\mathrm{p}<0.01$; $\mathrm{BH}$ vs. ER).

Metal elimination from killifish followed a biphasic loss pattern: during the first $24 \mathrm{~h}$ of depuration, the rapid loss corresponded to gut clearance of unassimilated metal, while the slower loss for the remaining $8 \mathrm{~d}$ corresponded to the physiological turnover of assimilated metal (Fig. 1). Nearly all of the metal bound to sediment from the 3 field locations was eliminated during the first $24 \mathrm{~h}$ of depuration. At the end of the $9 \mathrm{~d}$ depuration, the percentage of original metal retained was 0.5 to $0.9 \%$ As, 0.03 to $2 \% \mathrm{Cd}_{1} 0.05$ to $0.06 \% \mathrm{Cr}, 1.1$ to $1.9 \% \mathrm{Hg}(\mathrm{II})$, and 9.1 to $14 \% \mathrm{MeHg}$. Loss rate constants $\left(k_{\mathrm{ef}}\right)$ for $\mathrm{Hg}(\mathrm{II})\left(0.074\right.$ to $\left.0.113 \mathrm{~d}^{-1}\right)$, As $\left(0.057\right.$ to $\left.0.097 \mathrm{~d}^{-1}\right)$, and $\mathrm{Cd}(0.074$ to $0.089 \mathrm{~d}^{-1}$ ) were similar to one another and significantly higher than for MeHg (0.004 to $0.020 \mathrm{~d}^{-1}$ ) (Table 3). The $k_{\text {ef }}$ values for $\mathrm{Cr}$ could not be calculated due to nearly complete elimi- nation of the radioisotope. The $k_{\text {ef }}$ values for each field location did not differ significantly from one another for As, Cd, and $\mathrm{Hg}$ (II) ( $\mathrm{p}>0.05)$ but did differ for $\mathrm{MeHg}(\mathrm{p}<0.01$; ER vs. MI).

\section{Assimilation and retention of metals after algal intubation}

Following intubation with radiolabeled algae, the $\mathrm{AE}$ values were highest for $\mathrm{MeHg}(82 \%)$, followed by $\mathrm{Hg}(\mathrm{II})(18 \%)$, As (15\%), and Cd (10\%), and lowest for $\mathrm{Cr}(0.7 \%)$. For all metals, AEs were higher after intubation with algae than with sediment. If the sediment $\mathrm{AE}$ values for the 3 field locations are averaged, the AEs are 12-, 56-, 35-, 5.6-, and 6.8-fold higher for As, $\mathrm{Cd}, \mathrm{Cr}, \mathrm{Hg}(\mathrm{II})$, and $\mathrm{MeHg}$, respectively, after intubation with algae (Table 3).

Metals were eliminated from killifish following the same biphasic loss pattern noted after intubation with sediment (Fig. 2). Within the first $24 \mathrm{~h}, 80 \%$ of As, $89 \%$ of $\mathrm{Cd}, 90 \%$ of $\mathrm{Cr}, 74 \%$ of $\mathrm{Hg}(\mathrm{II})$, and $18 \%$ of $\mathrm{MeHg}$ had been eliminated. At the end of the $9 \mathrm{~d}$

Table 3. Fundulus heteroclitus. Assimilation efficiencies (AE) and loss rate constants $\left(k_{\mathrm{ef}}\right)$ calculated for killifish after intubation with radiolabeled sediment from 3 sites and algae. $\mathrm{n}=5$ for sediment and 9-10 for algae. $\mathrm{BH}$ : Baltimore Harbor, ER: Elizabeth River, MI: Mare Island, nd: not determined

\begin{tabular}{|c|c|c|c|c|c|c|c|}
\hline & & \multirow[b]{2}{*}{ Mean } & \multicolumn{2}{|c|}{$\mathrm{AE}(\%)$} & \multicolumn{3}{|c|}{$-k_{\text {ef }}\left(\mathrm{d}^{-1}\right)$} \\
\hline & & & SE & Range & Mean & SE & Range \\
\hline \multirow[t]{4}{*}{ As } & $\mathrm{BH}$ & 1.3 & 0.2 & $0.9-1.7$ & 0.097 & 0.018 & $0.043-0.136$ \\
\hline & ER & 0.8 & 0.1 & $0.5-1.1$ & 0.057 & 0.010 & $0.018-0.071$ \\
\hline & MI & 1.7 & 0.2 & $1.0-2.3$ & 0.081 & 0.004 & $0.073-0.091$ \\
\hline & Algae & 15 & 1 & $8.1-21$ & 0.223 & 0.019 & $0.109-0.318$ \\
\hline \multirow[t]{4}{*}{$\mathrm{Cd}$} & $\mathrm{BH}$ & 0.04 & 0.01 & $0.03-0.06$ & 0.089 & 0.035 & $0.006-0.196$ \\
\hline & ER & 0.3 & 0.05 & $0.2-0.5$ & 0.074 & 0.017 & $0.029-0.110$ \\
\hline & MI & 0.2 & 0.04 & $0.03-0.3$ & 0.080 & 0.017 & $0.024-0.123$ \\
\hline & Algae & 10 & 0.8 & $5.7-12$ & 0.041 & 0.008 & $0.013-0.091$ \\
\hline \multirow[t]{4}{*}{$\mathrm{Cr}$} & $\mathrm{BH}$ & 0.03 & 0.01 & $0.006-0.06$ & nd & nd & nd \\
\hline & ER & 0.02 & 0.01 & $0.006-0.05$ & nd & nd & nd \\
\hline & MI & 0.01 & 0.01 & $0.002-0.04$ & nd & nd & nd \\
\hline & Algae & 0.7 & 0.2 & 0.1-1.8 & 0.119 & 0.023 & $0.029-0.245$ \\
\hline \multirow[t]{4}{*}{$\mathrm{Hg}(\mathrm{II})$} & $\mathrm{BH}$ & 1.9 & 1.1 & $0.5-5.0$ & 0.088 & 0.025 & $0.044-0.148$ \\
\hline & ER & 3.7 & 1.3 & $0.7-8.5$ & 0.074 & 0.007 & $0.056-0.094$ \\
\hline & MI & 4.1 & 0.8 & $1.4-5.7$ & 0.113 & 0.013 & $0.065-0.139$ \\
\hline & Algae & 18 & 2 & $7.2-25$ & 0.085 & 0.009 & $0.032-0.125$ \\
\hline \multirow[t]{4}{*}{$\mathrm{MeHg}$} & $\mathrm{BH}$ & 10 & 3 & $4.4-18$ & 0.010 & 0.003 & $0.004-0.017$ \\
\hline & ER & 14 & 2 & $10-19$ & 0.004 & 0.002 & $0.0004-0.011$ \\
\hline & MI & 12 & 2 & $5.3-15$ & 0.020 & 0.003 & $0.009-0.025$ \\
\hline & Algae & 82 & 2 & $73-90$ & 0.009 & 0.001 & $0.004-0.015$ \\
\hline
\end{tabular}




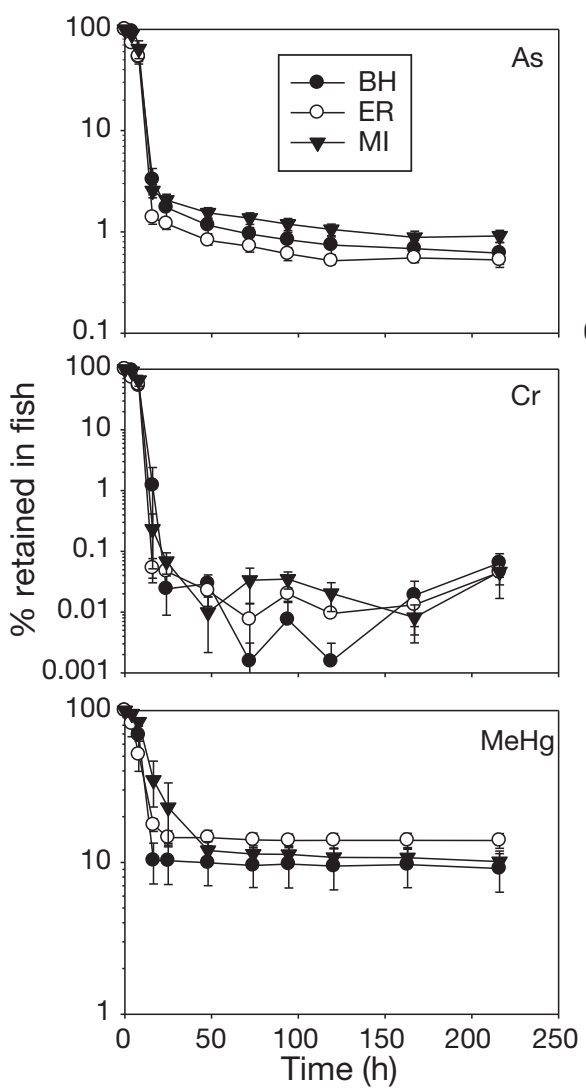

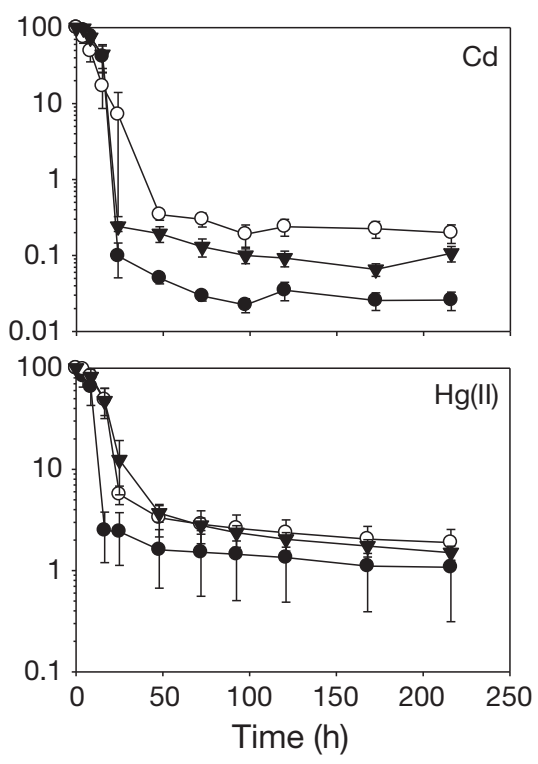

Fig. 1. Fundulus heteroclitus. Mean ( $\pm 1 \mathrm{SE}$ ) loss of $\mathrm{As}, \mathrm{Cd}, \mathrm{Cr}$, $\mathrm{Hg}(\mathrm{II})$, and $\mathrm{MeHg}$ from killifish over $9 \mathrm{~d}$ following intubation with radiolabeled Baltimore Harbor $(\mathrm{BH})$, Elizabeth River (ER), and Mare Island (MI) sediment. $\mathrm{n}=5$ per location respectively). The percentage of the body burden associated with each tissue compartment did not vary among the field locations, except for $\mathrm{Hg}$ (II) in the head (4-22\%) and viscera (68-91\%). Radioactivity concentrations were highest in the viscera for $\mathrm{Cd}, \mathrm{Hg}(\mathrm{II})$, and $\mathrm{MeHg}$ and nearly evenly concentrated between the viscera and body for As.

Following algal intubation, As and $\mathrm{MeHg}$ were predominantly associated with the body (48\% and $49 \%$, respectively), while $\mathrm{Cd}$ and $\mathrm{Hg}$ (II) were associated with the viscera ( $81 \%$ and $77 \%$, respectively). This is the same distribution pattern as observed after sediment intubation. Radioactivity concentrations were highest in the viscera for all metals. Radioactivity concentrations could not be compared among metals and between sediment and algae due to exposure to different metal concentrations. depuration period, the percentage of original metal retained was $2.3 \% \mathrm{As}, 7.3 \% \mathrm{Cd}, 0.3 \% \mathrm{Cr}, 8.8 \% \mathrm{Hg}$ (II), and $76 \% \mathrm{MeHg}$. The $k_{\mathrm{ef}}$ values were highest for As $\left(0.223 \mathrm{~d}^{-1}\right)$, followed by $\mathrm{Cr}\left(0.119 \mathrm{~d}^{-1}\right), \mathrm{Hg}$ (II) $(0.085$ $\left.\mathrm{d}^{-1}\right)$, and $\mathrm{Cd}\left(0.041 \mathrm{~d}^{-1}\right)$, and lowest for MeHg (0.009 $\mathrm{d}^{-1}$ ) (Table 3). These $k_{\mathrm{ef}}$ values were lower than that calculated for $\mathrm{Cd}$ and higher than that calculated for As following sediment intubation, whereas the values were comparable for $\mathrm{Hg}$ (II) and $\mathrm{MeHg}$.

\section{Tissue distribution and corresponding metal concentrations}

Table 4 shows the tissue distribution of $\mathrm{As}, \mathrm{Cd}$, $\mathrm{Hg}(\mathrm{II})$, and $\mathrm{MeHg}$ as the percentage of total body burden and radioactivity concentration $\left(\mathrm{Bq} \mathrm{g}^{-1}\right.$ dry weight) associated with each tissue compartment at the end of depuration after intubation with radiolabeled sediment and algae. The tissue distribution for $\mathrm{Cd}$ at $\mathrm{BH}$ and all $\mathrm{Cr}$ experiments could not be determined due to low detection in the fish. After intubation with sediment, As and MeHg were predominantly associated with the body (70-73\% and $42-43 \%$, respectively), whereas $\mathrm{Cd}$ and $\mathrm{Hg}$ (II) were associated with the viscera (81-97\% and 68-91\%,

\section{Modeling metal bioaccumulation in killifish}

The $\mathrm{tb}_{\frac{1}{2}}$ of metals in killifish was highest for $\mathrm{MeHg}$ (35-173 d), followed by similar tb ${ }_{1 / 2}$ values for As, Cd, and $\operatorname{Hg}(\mathrm{II})$ (7.1-12, 7.8-9.4, and 6.1-9.4 d, respectively) after intubation with radiolabeled sediment (Table 5). Assuming it takes 7 half-lives for all of the assimilated metal to be excreted, MeHg would be retained for 243 to $1213 \mathrm{~d}$, As for 50 to $85 \mathrm{~d}$, Cd for 55 to $66 \mathrm{~d}$, and $\mathrm{Hg}$ (II) for 43 to $66 \mathrm{~d}$. After intubation with radiolabeled algae, the $\mathrm{tb}_{1 / 2}$ was highest for $\mathrm{MeHg}$ (77 d), followed by $\mathrm{Cd}$ (17 d), $\mathrm{Hg}$ (II) (8.2 d), and $\mathrm{Cr}$ (5.8 d), and lowest for As (3.1 d) (Table 5). This corresponds to a retention time of $539 \mathrm{~d}$ for $\mathrm{MeHg}, 118 \mathrm{~d}$ for Cd, $57 \mathrm{~d}$ for $\mathrm{Hg}(\mathrm{II}), 41 \mathrm{~d}$ for $\mathrm{Cr}$, and $22 \mathrm{~d}$ for As.

The TTF values were $<1$ for $\mathrm{As}, \mathrm{Cd}, \mathrm{Hg}(\mathrm{II})$, and $\mathrm{MeHg}$ after sediment intubation (except ER MeHg; $\mathrm{TTF}=2.0$ ) regardless of field location, indicating that these metals would not be expected to biomagnify from sediments in killifish. TTF values could not be calculated for Cr due to nearly complete elimination of the radioisotope. After intubation with algae, $\mathrm{MeHg}$ was the only metal with a TTF $>1(\mathrm{TTF}=6.4)$, indicating that $\mathrm{MeHg}$ would be expected to biomagnify, whereas As, Cd, Cr, and $\mathrm{Hg}$ (II) had TTF $<1$, indicating that these metals would not be expected to biomagnify (Table 5). 

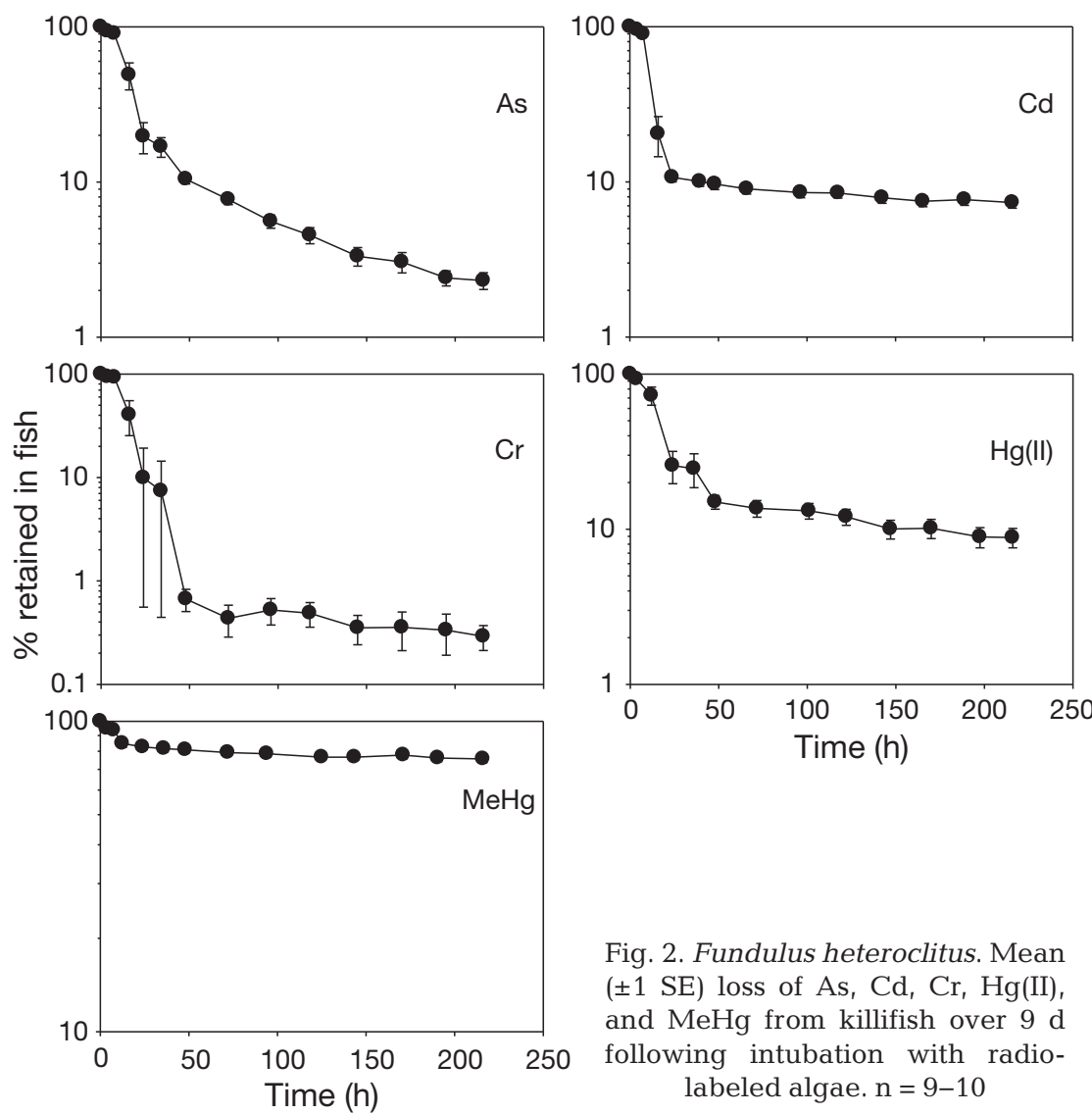

Fig. 2. Fundulus heteroclitus. Mean ( $\pm 1 \mathrm{SE}$ ) loss of As, Cd, Cr, $\mathrm{Hg}(\mathrm{II})$, and $\mathrm{MeHg}$ from killifish over $9 \mathrm{~d}$ following intubation with radiolabeled algae. $\mathrm{n}=9-10$

Table 4. Fundulus heteroclitus. Tissue distribution of metals in killifish at the end of $9 \mathrm{~d}$ depuration after intubation with radiolabeled sediment and algae. Values are the percentage of total body burden and radioactivity concentrations (Bq ${ }^{-1}$ dry weight) associated with each tissue compartment (head, viscera, or body). Tissue partitioning of $\mathrm{Cr}$ and $\mathrm{BH} \mathrm{Cd}$ could not be determined due to nearly complete elimination of the radioisotope. Values are means $\pm 1 \mathrm{SE} ; \mathrm{n}=5$ for sediment and 9-10 for algae. BH: Baltimore Harbor, ER: Elizabeth River, MI: Mare Island, nd: not determined

\begin{tabular}{|c|c|c|c|c|c|c|c|}
\hline & & \multicolumn{2}{|c|}{ Head } & \multicolumn{2}{|c|}{ Viscera } & \multicolumn{2}{|c|}{ Body } \\
\hline & & $\%$ & $\mathrm{~Bq}$ & $\%$ & $\mathrm{~Bq}$ & $\%$ & $\mathrm{~Bq}$ \\
\hline As & $\begin{array}{c}\text { BH } \\
\text { ER } \\
\text { MI } \\
\text { Algae }\end{array}$ & $\begin{array}{l}19 \pm 2 \\
21 \pm 2 \\
19 \pm 2 \\
21 \pm 2\end{array}$ & $\begin{array}{l}11 \pm 1 \\
10 \pm 1 \\
21 \pm 5 \\
15 \pm 2\end{array}$ & $\begin{aligned} 8 & \pm 2 \\
9 & \pm 3 \\
10 & \pm 0.8 \\
31 & \pm 5\end{aligned}$ & $\begin{array}{l}19 \pm 4 \\
18 \pm 7 \\
40 \pm 13 \\
93 \pm 25\end{array}$ & $\begin{array}{l}73 \pm 2 \\
70 \pm 1 \\
71 \pm 2 \\
48 \pm 3\end{array}$ & $\begin{array}{l}21 \pm 2 \\
17 \pm 3 \\
42 \pm 10 \\
19 \pm 3\end{array}$ \\
\hline $\mathrm{Cd}$ & $\begin{array}{c}\text { BH } \\
\text { ER } \\
\text { MI } \\
\text { Algae }\end{array}$ & $\begin{array}{c}\text { nd } \\
2 \pm 1 \\
7 \pm 3 \\
8 \pm 1\end{array}$ & $\begin{array}{c}\text { nd } \\
0.13 \pm 0.08 \\
0.13 \pm 0.06 \\
5.9 \pm 0.6\end{array}$ & $\begin{array}{c}\text { nd } \\
97 \pm 1 \\
91 \pm 4 \\
81 \pm 2\end{array}$ & $\begin{array}{c}\text { nd } \\
32 \pm 12 \\
8 \pm 3 \\
197 \pm 47\end{array}$ & $\begin{array}{c}\text { nd } \\
1 \pm 0.7 \\
2 \pm 2 \\
11 \pm 2\end{array}$ & $\begin{array}{c}\text { nd } \\
0.09 \pm 0.07 \\
0.01 \pm 0.01 \\
5.1 \pm 1.3\end{array}$ \\
\hline $\operatorname{Hg}(\mathrm{II})$ & $\begin{array}{c}\text { BH } \\
\text { ER } \\
\text { MI } \\
\text { Algae }\end{array}$ & $\begin{aligned} 22 & \pm 8 \\
4 & \pm 1 \\
7 & \pm 1 \\
12 & \pm 0.8\end{aligned}$ & $\begin{array}{l}1.8 \pm 0.3 \\
3.0 \pm 0.9 \\
6.8 \pm 1.3 \\
1.7 \pm 0.2\end{array}$ & $\begin{array}{l}68 \pm 5 \\
91 \pm 3 \\
86 \pm 3 \\
77 \pm 1\end{array}$ & $\begin{aligned} 18 & \pm 6 \\
170 & \pm 43 \\
148 & \pm 22 \\
28 & \pm 3\end{aligned}$ & $\begin{aligned} 10 & \pm 3 \\
5 & \pm 2 \\
7 & \pm 3 \\
11 & \pm 0.7\end{aligned}$ & $\begin{array}{l}0.8 \pm 0.4 \\
1.6 \pm 0.6 \\
3.9 \pm 1.7 \\
0.8 \pm 0.1\end{array}$ \\
\hline $\mathrm{MeHg}$ & $\begin{array}{c}\text { BH } \\
\text { ER } \\
\text { MI } \\
\text { Algae }\end{array}$ & $\begin{array}{l}22 \pm 1 \\
22 \pm 1 \\
21 \pm 2 \\
24 \pm 0.4\end{array}$ & $\begin{aligned} 51 & \pm 7 \\
107 & \pm 11 \\
64 & \pm 11 \\
36 & \pm 3\end{aligned}$ & $\begin{array}{l}36 \pm 3 \\
35 \pm 3 \\
37 \pm 1 \\
27 \pm 1\end{array}$ & $\begin{aligned} 181 & \pm 39 \\
419 & \pm 62 \\
240 & \pm 31 \\
78 & \pm 8\end{aligned}$ & $\begin{array}{l}42 \pm 2 \\
43 \pm 1 \\
42 \pm 0.8 \\
49 \pm 1\end{array}$ & $\begin{aligned} 50 & \pm 8 \\
110 & \pm 11 \\
65 & \pm 9 \\
38 & \pm 3\end{aligned}$ \\
\hline
\end{tabular}

\section{DISCUSSION}

\section{Assimilation of metals after sediment intubation}

To our knowledge, the present study is the first to investigate the bioavailability of several metals associated with contaminated sediment for fish. Because no significant differences were noted in the TTF of metals among the 3 sediments (except ER $\mathrm{MeHg}$ ), it is apparent that sediment geochemistry differences among the 3 sediment sites (Baumann \& Fisher 2011) did not influence the $A E$ and $k_{\text {ef }}$ of each metal in killifish. The AE values calculated for killifish in the present study are much lower than those calculated for deposit-feeding polychaetes and marine bivalves that ingested radiolabeled sediment. AE values in polychaetes ranged from 43 to $83 \%$ for $\mathrm{MeHg}, 7$ to $30 \%$ for $\mathrm{Hg}(\mathrm{II})$, 1.5 to $59 \%$ for Cd, 1.2 to $12 \%$ for As, and 0.7 to $4.6 \%$ for $\mathrm{Cr}$ (Wang et al. 1998, 1999, Baumann \& Fisher 2011). AE values in bivalves ranged from 5 to $87 \%$ (generally $>30 \%$ ) for $\mathrm{MeHg}, 6$ to $35 \%$ for $\mathrm{Cd}_{1}<1$ to $20 \%$ for $\mathrm{Cr}$, and 1 to $9 \%$ for $\mathrm{Hg}$ (II) (Gagnon \& Fisher 1997, Wang et al. 1997, Griscom et al. $2000,2002 \mathrm{a}$ ). No literature values could be found to compare As values in bivalves to those calculated for killifish in the present study. For all of the metals investigated in the present study, the sediment $\mathrm{AE}$ values are lower than the algal AE values; this observation was also noted in another study using the clam Macoma balthica (Griscom et al. 2002a). The difference in $\mathrm{AE}$ between sediment and algae could be due in part to what fraction the metal is bound to in the sediment. In algae, the metal is bound to the more labile organic matter, whereas in the sediment, little metal is bound to labile organic matter, and this metal is much less bioavailable. It should also be noted that because the fish were intubated and did not feed naturally, the $\mathrm{AE}$ values may be 
Table 5. Fundulus heteroclitus. Model predicted biological half-lives $\left(\mathrm{tb}_{1 / 2}\right)$ and trophic transfer factors (TTF) of metals in killifish following intubation with radiolabeled sediment and algae. Values used are in Table 3. BH: Baltimore Harbor, ER: Elizabeth River, MI: Mare Island, nd: not determined

\begin{tabular}{|c|c|c|c|}
\hline & & $\mathrm{tb}_{1 / 2}(\mathrm{~d})$ & TTF \\
\hline \multirow[t]{4}{*}{ As } & $\mathrm{BH}$ & 7.1 & 0.009 \\
\hline & ER & 12 & 0.010 \\
\hline & MI & 8.6 & 0.015 \\
\hline & Algae & 3.1 & 0.047 \\
\hline \multirow[t]{4}{*}{$\mathrm{Cd}$} & $\mathrm{BH}$ & 7.8 & 0.0003 \\
\hline & ER & 9.4 & 0.0028 \\
\hline & MI & 8.7 & 0.0018 \\
\hline & Algae & 17 & 0.17 \\
\hline \multirow[t]{4}{*}{$\mathrm{Cr}$} & $\mathrm{BH}$ & nd & nd \\
\hline & ER & nd & nd \\
\hline & MI & nd & nd \\
\hline & Algae & 5.8 & 0.004 \\
\hline \multirow[t]{4}{*}{ Hg(II) } & $\mathrm{BH}$ & 7.9 & 0.015 \\
\hline & ER & 9.4 & 0.035 \\
\hline & MI & 6.1 & 0.025 \\
\hline & Algae & 8.2 & 0.15 \\
\hline \multirow[t]{4}{*}{$\mathrm{MeHg}$} & $\mathrm{BH}$ & 69 & 0.7 \\
\hline & ER & 173 & 2.0 \\
\hline & MI & 35 & 0.4 \\
\hline & Algae & 77 & 6.4 \\
\hline
\end{tabular}

underestimated because the sediment was forced into the intestine during the intubation procedure.

The lower AE values noted for killifish compared to deposit-feeding polychaetes and bivalves could be a result of the difference in gut physiology among these organisms. The $\mathrm{pH}$ of gut fluid in worms $(\mathrm{pH}$ 6.88 in Nereis succinea; Ahrens et al. 2001) and bivalves (pH 5.0 in the clam Macoma balthica and 5.6 in the mussel Mytilus edulis; Griscom et al. 2002b) is neutral or mildly acidic, whereas the $\mathrm{pH}$ of killifish gut fluid is mildly acidic to alkaline. A study by Babkin \& Bowie (1928) determined that the intestinal fluid in fasting killifish has a $\mathrm{pH}$ between 8.0 and 9.2, and fish have a pH between 8.4 and 9.0 after feeding on clams. More recently, Wood et al. (2010) found a comparable fasting $\mathrm{pH}(7.7)$ but determined that the $\mathrm{pH}$ of the intestinal fluid was 5.7 in seawater killifish and 6.8 in freshwater killifish 1 to $3 \mathrm{~h}$ after feeding on fish pellets. The $\mathrm{pH}$ can influence the solubility of metal from the sediment fraction to which it is bound; metals bound to the acid-volatile sulfide (AVS) and iron-oxide fractions are extracted in the low $\mathrm{pH}$ of the clam and mussel gut fluid, and the proportion of metal extracted is greater in the clam, which has a more acidic gut fluid (Griscom et al. 2002b). Baumann \& Fisher (2011) calculated that 13 to $42 \%$ of As,
33 to $50 \%$ of $\mathrm{Cd}$, and 75 to $91 \%$ of $\mathrm{Cr}$ was bound to the AVS and iron- and manganese-oxide fractions $2 \mathrm{~d}$ after the sediment from the 3 field locations used in the present study were radiolabeled directly. The $\mathrm{pH}$ of the killifish intestinal fluid would not be expected to affect the bioavailability of metal bound to the AVS and iron-oxide fractions. Furthermore, the killifish does not have a stomach (Babkin \& Bowie 1928); because the stomach secretes gastric acid, the absence of the stomach can provide some explanation for the higher $\mathrm{pH}$ of the intestinal fluid. Worms also have a high concentration of amino acids in their digestive fluid, which can solubilize metals from sediment, and surfactants that can solubilize polycyclic aromatic hydrocarbons (Mayer et al. 1996, Ahrens et al. 2001). Mayer et al. (1996) investigated the solubility of metals in the gut fluid of the lugworm Arenicola marina and the sea cucumber Parastichopus californicus; the lugworm solubilized more metal as a result of a much higher dissolved amino acid concentration. This has also been observed in fish: when sturgeon and catfish gut fluid were exposed to sediment labeled with $\mathrm{MeHg}$, the sturgeon solubilized more MeHg in the gut fluid due to a higher concentration of amino acids (Leaner \& Mason 2002a).

\section{Assimilation of metals after algal intubation}

The wide range of $\mathrm{AE}$ values observed after killifish were intubated with radiolabeled algae $(0.7 \%$ for $\mathrm{Cr}$ to $82 \%$ for $\mathrm{MeHg}$ ) indicates there is large variability in AE among the metals. The general ranking of $\mathrm{AE}(\mathrm{MeHg}>\mathrm{Hg}(\mathrm{II})>\mathrm{As}>\mathrm{Cd}>\mathrm{Cr}$ ) is identical to the ranking observed after sediment intubation. To our knowledge, the present study is the first to calculate $\mathrm{AE}$ values after fish have consumed radiolabeled algae for As, Cd, Cr, and $\mathrm{Hg}(\mathrm{II})$. Leaner \& Mason (2004) calculated an AE of $90 \%$ for the sheepshead minnow Cyprinodon variegatus fed $\mathrm{MeHg}$ radiolabeled pellets of the green alga Tetraselmis. Our AE value of $82 \%$ could be slightly lower because the sheepshead minnows were fed naturally, whereas the killifish used in the present study were intubated. The $\mathrm{Cd}, \mathrm{Hg}(\mathrm{II})$, and $\mathrm{MeHg} \mathrm{AE}$ values calculated from the present study fall within the range of literature values for freshwater and marine fish fed zooplankton and worm prey $(2.7-39 \%, 8-51 \%$, and $56-95 \%$, respectively) (Reinfelder \& Fisher 1994, Ni et al. 2000, Xu \& Wang 2002, Wang \& Wong 2003, Pickhardt et al. 2006, Mathews \& Fisher 2008, Dutton \& Fisher 2010, 2011). Our calculated As AE (15\%) is higher than that calculated for killifish fed amphipod 
prey $(9.4 \%$; Dutton \& Fisher 2011), and our calculated $\mathrm{Cr} \mathrm{AE}(0.7 \%)$ is at the lower end of the range observed for fish fed amphipod and worm prey ( 0.2 to $19 \%$; Ni et al. 2000, Dutton \& Fisher 2011).

The large range in $\mathrm{AE}$ values from algae observed among the metals could be due to varying cellular distributions of the metals in Dunaliella tertiolecta cells. Numerous studies have found that the AE of ingested elements in herbivores is related to the cytoplasmic content of these elements in algae, first noted for diatoms by Reinfelder \& Fisher (1991), although variations in cellular distributions of elements among different algal taxa have been noted (Ng et al. 2005), and the relationship to herbivore AE may vary. This relationship between cellular distribution of metals and $\mathrm{AE}$ in herbivores may explain our findings, where the MeHg $\mathrm{AE}$ is 4.6-fold higher than that for $\mathrm{Hg}$ (II). Pickhardt \& Fisher (2007) found that 59 to $64 \%$ of $\mathrm{MeHg}$ is associated with the cytoplasm in freshwater phytoplankton, whereas only 9 to $16 \%$ of $\mathrm{Hg}$ (II) is associated with the cytoplasm and is therefore less assimilable when ingested. Furthermore, it has been found that $>98 \%$ of $\mathrm{Cr}$ is bound to algal cell surfaces, and when fed to the mussel Mytilus edulis, the AE ranged between 0.2 and $1.3 \%$ (Wang \& Fisher 1996), comparable to our low Cr AE value of $0.7 \%$. This relationship has also been observed when fish were fed zooplankton; AE values were lower in fish when a large proportion of the metal was associated with the zooplankton exoskeleton. For example, $97 \%$ of $\mathrm{Cd}$ in copepods was bound to the exoskeleton, and fish that fed on these copepods assimilated $2.7 \%$, due to the fish being unable to digest the exoskeleton (Reinfelder \& Fisher 1994). This was also noted when killifish were fed radiolabeled amphipods and worms, with higher AE values for $\mathrm{Cr}$ and $\mathrm{Hg}$ (II) after the fish were fed soft-bodied worms (Dutton \& Fisher 2011).

\section{Loss of metals after sediment and algal intubations}

The $k_{\text {ef }}$ values after sediment and algal intubations were similar for $\mathrm{Hg}(\mathrm{II})$ and $\mathrm{MeHg}$, higher for As after algal intubation, and higher for Cd after sediment intubation. The physiological turnover rate of metals probably reflects the turnover rates of the tissues in which the metals reside. The tissue distributions of $\mathrm{Hg}$ (II) and MeHg were similar for sediment and algal diets (Table 4), and therefore, their $k_{\text {ef }}$ did not vary between the diets. In contrast, more As and less $\mathrm{Cd}$ was in the viscera following the algal diet than the sediment diet (Table 4), matching their $k_{\text {ef }}$ patterns.
This suggests that the $k_{\text {ef }}$ of each metal was principally related to the loss of metal from the viscera.

The algal As $k_{\text {ef }}$ value calculated in the present study $\left(0.223 \mathrm{~d}^{-1}\right)$ is similar to that calculated after killifish were fed radiolabeled amphipods $\left(0.287 \mathrm{~d}^{-1}\right)$, whereas the sediment $k_{\text {ef }}$ values were $\sim 3$-fold lower (Dutton \& Fisher 2011). The calculated algal $k_{\text {ef }}$ for Cd $\left(0.041 \mathrm{~d}^{-1}\right)$ falls within the range calculated in other studies in which fish were fed worm and zooplankton prey $\left(0.03-0.073 \mathrm{~d}^{-1}\right.$; Xu \& Wang 2002, Mathews \& Fisher 2008, Dutton \& Fisher 2010, 2011). The $\mathrm{Cr}$ algal $k_{\text {ef }}$ value calculated in the present study $\left(0.119 \mathrm{~d}^{-1}\right)$ is 1.9 -fold higher than after killifish were fed radiolabeled worms $\left(0.064 \mathrm{~d}^{-1}\right.$; Dutton \& Fisher 2011). The sediment and algal $k_{\text {ef }}$ values calculated in the present study for $\mathrm{Hg}$ (II) and $\mathrm{MeHg}$ (0.074 to 0.113 and 0.004 to $0.020 \mathrm{~d}^{-1}$, respectively) fall within the range of those calculated in other studies using freshwater and marine fish fed zooplankton and worm prey (0.003 to $0.194 \mathrm{~d}^{-1}$ for $\mathrm{Hg}$ (II) and 0.007 to $0.018 \mathrm{~d}^{-1}$ for MeHg; Pickhardt et al. 2006, Mathews \& Fisher 2008, Dutton \& Fisher 2010, 2011).

\section{Tissue distribution of metals}

The tissue distribution of the metals investigated in the present study fall within the range of values calculated in other studies when fish were fed radiolabeled prey. Of all of the metals examined, Cd shows the greatest variability in literature values. Our study concluded that 81 to $97 \%$ of $\mathrm{Cd}$ remains associated with the viscera, which is similar to values calculated in another killifish study ( $85 \%$ associated with the intestine; Dutton \& Fisher 2011) and mangrove snapper Lutjanus argentimaculatus (81\%; Xu \& Wang 2002) but much higher than the percentage calculated for the Atlantic silverside Menidia menidia (13 to 16\%; Dutton \& Fisher 2010), striped bass Morone saxatilis (20\%; Baines et al. 2002), and killifish (50\%; Mathews \& Fisher 2008). This range of values indicates that some fish are better protected against the gastrointestinal uptake of $\mathrm{Cd}$ than others. Cd shares the same gastrointestinal uptake pathway as $\mathrm{Ca}$, and elevated levels of Ca reduce the uptake of Cd (Franklin et al. 2005).

The different tissue distributions of $\mathrm{Hg}$ (II) and $\mathrm{MeHg}$ indicate that $\mathrm{MeHg}$ can more readily pass across the intestinal wall, after which it is redistributed around the body via the blood and accumulates in the fillet, which is sulfur-rich. A study by Leaner \& Mason (2002b) found that MeHg binds to cysteine and crosses the intestine via an amino acid uptake pathway in the channel catfish Ictalurus punctatus. 
The higher percentage distribution and concentration of $\mathrm{MeHg}$ in the body poses a risk to killifish predators, including the blue crab and striped bass (Kneib 1986, Hartman \& Brandt 1995), and therefore potentially human consumers. The tissue distribution of $\mathrm{Hg}(\mathrm{II})$ and $\mathrm{MeHg}$ presented in our study are comparable to other literature values. For Hg(II), Pickhardt et al. (2006) found that 92 to $96 \%$ of $\mathrm{Hg}$ (II) was associated with the viscera in mosquitofish Gambusia affinis and 67.5 to $73 \%$ in redear sunfish Lepomis microlophus, 28 to $72 \%$ was associated with the viscera in the Atlantic silverside (Dutton \& Fisher 2010), and 81 to $84 \%$ was associated with the viscera in another killifish study (Dutton \& Fisher 2011). For $\mathrm{MeHg}, 54 \%$ of $\mathrm{MeHg}$ was associated with the body in the redear sunfish and $68 \%$ in mosquitofish (Pickhardt et al. 2006), 51 to $57 \%$ in the Atlantic silverside (Dutton \& Fisher 2010), and 51 to $58 \%$ in 2 other killifish studies (Mathews \& Fisher 2008, Dutton \& Fisher 2011), which are comparable but slightly higher than our values of 42 to $49 \%$.

Like $\mathrm{MeHg}$, As was also redistributed around the body, where $48 \%$ was associated with the body after algal intubation and 70 to $73 \%$ after sediment intubation. The reason for this difference is not apparent to us, although it is noteworthy that very little As was acquired from either diet. Literature values for the tissue distribution of As in fish are limited. One laboratory study found that $62 \%$ of As was associated with the body following a $9 \mathrm{~d}$ depuration after acquiring As from amphipods (Dutton \& Fisher 2011). Another study analyzed field-collected herring, cod, and flounder and found that As accumulates in the fillet (Larsen \& Francesconi 2003). Arsenate is known to behave as a phosphate analog in phytoplankton, sharing the same uptake pathway (Sanders \& Windom 1980), and after arsenate is taken up, it is reduced to a variety of organoarsenic species, including arsenobetaine (Neff 1997). A recent study found that the phosphate transporter, NaPi-IIb1, is most likely responsible for arsenate accumulation in zebrafish tissues (Beene et al. 2011). Speciation of As in field-collected fish found that 89 to $100 \%$ of As in the muscle tissue was present as arsenobetaine, whereas arsenate accounted for $0 \%$; however, 0 to $38 \%$ of the As in the intestine was present as arsenate (Kirby \& Maher 2002). We did not speciate As in the fish tissue in the present study, so we cannot conclude if this is the case for killifish. The tissue distribution data from the present study and others indicate that once the metal has been solubilized from the ingested prey or substrate, it is remobilized around the body in the same way, regardless of the source.

\section{Biomagnification of metals in killifish}

The TTF values were $<1$ after sediment intubation for $\mathrm{As}, \mathrm{Cd}$, and $\mathrm{Hg}$ (II) at all 3 field locations and for $\mathrm{MeHg}$ at $\mathrm{BH}$ and $\mathrm{MI}$, indicating that these metals are not expected to biomagnify from sediment to killifish. Killifish intubated with sediment from ER had a TTF $>1$, indicating that $\mathrm{MeHg}$ will biomagnify in this field location. TTF values could not be calculated for $\mathrm{Cr}$ due to elimination of the radioisotope. After intubation with algae, MeHg was the only metal expected to biomagnify (TTF $=6.4$ ) due to a high assimilation and low elimination rate. In comparison, $\mathrm{As}, \mathrm{Cd}, \mathrm{Cr}$, and $\mathrm{Hg}$ (II) had a TTF < 1 due to low assimilation and high elimination rates. The IR of sediment and algae is most likely lower than the $0.07 \mathrm{~g}^{-1} \mathrm{~g}^{-1} \mathrm{~d}^{-1}$ value used to calculate the TTF in the present study. Therefore, the TTF of metals bound to sediment and algae are likely to be even lower than the values calculated here. MeHg associated with ER sediment and algae will not biomagnify at this trophic step if the IR of ER sediment is $<0.04 \mathrm{~g}^{-1} \mathrm{~g}^{-1} \mathrm{~d}^{-1}$ and the IR of algae is $<0.011 \mathrm{~g}^{-1} \mathrm{~g}^{-1} \mathrm{~d}^{-1}$.

To our knowledge, the present study is the first to calculate TTF values after exposure to radiolabeled sediment and algae, so no comparisons can be made to other studies. Following exposure to radiolabeled algae, $\mathrm{Hg}(\mathrm{II})$ and $\mathrm{MeHg}$ TTF values are similar to those calculated for killifish that consumed radiolabeled amphipods and worms, while the TFF values are higher for As and Cd and lower for Cr (Dutton \& Fisher 2011). The TTF values following exposure to radiolabeled sediment compared to amphipods and worms were lower for $\mathrm{Cd}$ at all 3 locations and for $\mathrm{MeHg}$ at $\mathrm{BH}$ and $\mathrm{MI}$ but were similar for As at all 3 locations and for MeHg at ER. The Hg(II) TTF values were similar to values calculated after killifish consumed amphipods but higher than that calculated after killifish consumed worms (Dutton \& Fisher 2011).

\section{Sediment and algae as a source of metals to killifish}

Metals can accumulate to high concentrations in industrialized coastal regions. The present study concludes that metals bound to sediment are not a significant direct source of metals to fish due to their low bioavailability. This reduces the likelihood of health implications to the killifish themselves and their predators. Killifish do not actively consume sediment, and the risk of metal accumulation from incidental uptake while consuming benthic prey is minimal. Algae, however, can be an important food 
source for killifish, especially in salt marshes (Kneib \& Stiven 1978, Kneib 1986), and can be a significant source of metal, especially MeHg.

Acknowledgements. We thank G. Cutter and the captain and crew of the RV 'Fay Slover' and RV 'Questuary' for help collecting water and sediment, R. Cerrato, P. Field, D. Hirschberg, L. Holt, B. Jackson and A. Smirnov for sediment and water analyses, and 3 anonymous reviewers for helpful comments on the manuscript. This research was supported by SERDP W912HQ06C0014/W74RDV53574241 and National Science Foundation Award No. 0549370.

\section{LITERATURE CITED}

Abraham BJ (1985) Species profiles: life histories and environmental requirements of coastal fishes and invertebrates (Mid-Atlantic): mummichog and striped killifish. US Fish Wildl Serv Biol Rep 82(11.40). US Army Corps of Engineers, TR EL-82-4, Louisville, KY

> Ahrens MJ, Hertz J, Lamoureux EM, Lopez GR, McElroy AE, Brownawell BJ (2001) The role of digestive surfactants in determining bioavailability of sediment-bound hydrophobic organic contaminants to 2 deposit-feeding polychaetes. Mar Ecol Prog Ser 212:145-157

> Allen EA, Fell PE, Peck MA, Gieg JA, Guthke CR, Newkirk MD (1994) Gut contents of common mummichogs, Fundulus heteroclitus L., in a restored and impounded marsh and in natural reference marshes. Estuaries 17:462-471

Babkin BP, Bowie DJ (1928) The digestive system and its function in Fundulus heteroclitus. Biol Bull 54:254-277

Baines SB, Fisher NS, Stewart R (2002) Assimilation and retention of selenium and other trace elements from crustacean food by juvenile striped bass (Morone saxatilis). Limnol Oceanogr 47:646-655

Baumann Z, Fisher NS (2011) Relating the sediment phase speciation of arsenic, cadmium, and chromium with their bioavailability for the deposit-feeding polychaete Nereis succinea. Environ Toxicol Chem 30:747-756

Beene LC, Halluer J, Yoshinaga M, Hamdi M, Liu Z (2011) Pentavalent arsenate transport by zebrafish phosphate transporter NaPi-IIb1. Zebrafish 8:125-131

Dutton J, Fisher NS (2010) Intraspecific comparisons of metal bioaccumulation in the juvenile Atlantic silverside Menidia menidia. Aquat Biol 10:211-226

$>$ Dutton J, Fisher NS (2011) Bioaccumulation of As, Cd, Cr, $\mathrm{Hg}(\mathrm{II})$, and $\mathrm{MeHg}$ in killifish (Fundulus heteroclitus) from amphipod and worm prey. Sci Total Environ 409: 3438-3447

Fisher NS, Reinfelder JR (1995) The trophic transfer of metals in marine systems. In: Tessier A, Turner DR (eds) Metal speciation and bioavailability in aquatic systems. John Wiley \& Sons, New York, NY, p 363-406

- França S, Vinagre C, Caçador I, Cabral HN (2005) Heavy metal concentrations in sediment, benthic invertebrates and fish in three salt marsh areas subjected to different pollution loads in the Tagus estuary (Portugal). Mar Pollut Bull 50:998-1003

> Franklin NM, Glover CN, Nicol JA, Wood CM (2005) Calcium/cadmium interactions at uptake surfaces in rainbow trout: waterborne versus dietary routes of exposure. Environ Toxicol Chem 24:2954-2964

Gagnon C, Fisher NS (1997) Bioavailability of sediment- bound methyl and inorganic mercury to a marine bivalve. Environ Sci Technol 31:993-998

Griscom SB, Fisher NS, Luoma SN (2000) Geochemical influences on assimilation of sediment-bound metals in clams and mussels. Environ Sci Technol 34:91-99

Griscom SB, Fisher NS, Luoma SN (2002a) Kinetic modeling of $\mathrm{Ag}, \mathrm{Cd}$ and Co bioaccumulation in the clam Macoma balthica: quantifying dietary and dissolved sources. Mar Ecol Prog Ser 240:127-141

> Griscom SB, Fisher NS, Aller RC, Lee BG (2002b) Effects of gut chemistry in marine bivalves on the assimilation of metals from ingested sediment particles. J Mar Res 60:101-120

> Guillard RRL, Ryther JH (1962) Studies of marine planktonic diatoms I. Cyclotella nana Hustedt, and Detonula confervacea (Cleve). Can J Microbiol 8:229-239

$>$ Hartman KJ, Brandt SB (1995) Trophic resource partitioning, diets, and growth of sympatric estuarine predators. Trans Am Fish Soc 124:520-537

Kennish MJ (1997) Practical handbook of estuarine and marine pollution. CRC Press, Boca Raton, FL

- Kirby J, Maher W (2002) Tissue accumulation and distribution of arsenic compounds in three marine fish species: relationship to trophic position. Appl Organomet Chem 16:108-115

Kneib RT (1986) The role of Fundulus heteroclitus in salt marsh trophic dynamics. Am Zool 26:259-269

Kneib RT, Stiven AE (1978) Growth, reproduction, and feeding of Fundulus heteroclitus (L.) on a North Carolina salt marsh. J Exp Mar Biol Ecol 31:121-140

Larsen EH, Francesconi KA (2003) Arsenic concentrations correlate with salinity for fish taken from the North Sea and Baltic waters. J Mar Biol Assoc UK 83:283-284

Leaner JJ, Mason RP (2002a) Factors controlling the bioavailability of ingested methylmercury to channel catfish and Atlantic sturgeon. Environ Sci Technol 36: 5124-5129

> Leaner JJ, Mason RP (2002b) Methylmercury accumulation and fluxes across the intestine of channel catfish, Ictalurus punctatus. Comp Biochem Physiol C 132:247-259

- Leaner JJ, Mason RP (2004) Methylmercury uptake and distribution kinetics in the sheepshead minnows, Cyprinodon variegatus, after exposure to $\mathrm{CH}_{3} \mathrm{Hg}$-spiked food. Environ Toxicol Chem 23:2138-2146

> Luoma SN (1989) Can we determine the biological availability of sediment-bound trace elements? Hydrobiologia 176-177:379-396

Mathews T, Fisher NS (2008) Evaluating the trophic transfer of cadmium, polonium, and methylmercury in an estuarine food chain. Environ Toxicol Chem 27:1093-1101

> Mayer LM, Chen Z, Findlay RH, Fang J and others (1996) Bioavailability of sedimentary contaminants subject to deposit-feeding digestion. Environ Sci Technol 30: 2641-2645

- McMahon KW, Johnson BJ, Ambrose WG Jr (2005) Diet and movement of the killifish, Fundulus heteroclitus, in a Maine salt marsh assessed using gut contents and stable isotope analyses. Estuaries 28:966-973

Neff JM (1997) Ecotoxicology of arsenic in the marine environment. Environ Toxicol Chem 16:917-927

> Ng TYT, Amiard-Triquet C, Rainbow PS, Amiard JC, Wang WX (2005) Physico-chemical form of trace metals accumulated by phytoplankton and their assimilation by filter-feeding invertebrates. Mar Ecol Prog Ser 299: 179-191 
Ni IH, Wang WX, Tam YK (2000) Transfer of Cd, Cr and Zn from zooplankton prey to mudskipper Periophthalmus cantonensis and glassy Ambassis urotaenia fishes. Mar Ecol Prog Ser 194:203-210

Nieboer E, Richardson DHS (1980) The replacement of the nondescript term 'heavy metals' by a biologically and chemically significant classification of metal ions. Environ Pollut B 1:3-26

Pickhardt PC, Fisher NS (2007) Accumulation of inorganic and methylmercury by freshwater phytoplankton in two contrasting water bodies. Environ Sci Technol 41:125-131

Pickhardt PC, Stepanova M, Fisher NS (2006) Contrasting uptake routes and tissue distributions of inorganic and methylmercury in mosquitofish (Gambusia affinis) and redear sunfish (Lepomis microlophus). Environ Toxicol Chem 25:2132-2142

Prinslow TE, Valiela I, Teal JM (1974) The effect of detritus and ration size on the growth of Fundulus heteroclitus (L.). J Exp Mar Biol Ecol 16:1-10

Reinfelder JR, Fisher NS (1991) The assimilation of elements ingested by marine copepods. Science 251:794-796

Reinfelder JR, Fisher NS (1994) Retention of elements absorbed by juvenile fish (Menidia menidia, Menidia beryllina) from zooplankton prey. Limnol Oceanogr 39:1783-1789

Reinfelder JR, Fisher NS, Luoma SN, Nichols JW, Wang WX (1998) Trace element trophic transfer in aquatic organisms: a critique of the kinetic model approach. Sci Total Environ 219:117-135

Rouleau C, Block M (1997) Fast and high-yield synthesis of radioactive $\mathrm{CH}_{3}{ }^{203} \mathrm{Hg}(\mathrm{II})$. Appl Organomet Chem 11: 751-753

Sanders JG, Windom HL (1980) The uptake and reduction of arsenic species by marine algae. Estuar Coast Mar Sci 10:555-567

Editorial responsibility: Helmut Segner, Bern, Switzerland
Schlekat CE, Decho AW, Chandler GT (2000) Bioavailability of particle-associated silver, cadmium, and zinc to the estuarine amphipod Leptocheirus plumulosus through dietary ingestion. Limnol Oceanogr 45:11-21

Thomann RV (1981) Equilibrium model of fate of microcontaminants in diverse aquatic food chains. Can J Fish Aquat Sci 38:280-296

- Wang WX, Fisher NS (1996) Assimilation of trace elements and carbon by the mussel Mytilus edulis: effects of food composition. Limnol Oceanogr 41:197-207

Wang WX, Wong RSK (2003) Bioaccumulation kinetics and exposure pathways of inorganic mercury and methylmercury in a marine fish, the sweetlips Plectorhinchus gibbosus. Mar Ecol Prog Ser 261:257-268

> Wang WX, Fisher NS, Luoma SN (1996) Kinetic determinations of trace element bioaccumulation in the mussel Mytilus edulis. Mar Ecol Prog Ser 140:91-113

> Wang WX, Griscom SB, Fisher NS (1997) Bioavailability of $\mathrm{Cr}(\mathrm{III})$ and $\mathrm{Cr}(\mathrm{VI})$ to marine mussels from solute and particulate pathways. Environ Sci Technol 31:603-611

Wang WX, Stupakoff I, Gagnon C, Fisher NS (1998) Bioavailability of inorganic and methylmercury to a marine deposit-feeding polychaete. Environ Sci Technol 32:2564-2571

> Wang WX, Stupakoff I, Fisher NS (1999) Bioavailability of dissolved and sediment-bound metals to a marine deposit-feeding polychaete. Mar Ecol Prog Ser 178:281-293

> Wood CM, Bucking C, Grosell M (2010) Acid-base responses to feeding in intestinal $\mathrm{Cl}^{-}$uptake in freshwater- and seawater-acclimated killifish, Fundulus heteroclitus, an agastric euryhaline teleost. J Exp Biol 213: 2681-2692

Xu Y, Wang WX (2002) Exposure and potential food chain transfer factor of $\mathrm{Cd}, \mathrm{Se}$, and $\mathrm{Zn}$ in marine fish Lutjanus argentimaculatus. Mar Ecol Prog Ser 238:173-186

Submitted: January 2, 2012; Accepted: April 11, 2012

Proofs received from author(s): May 31, 2012 